Колісниченко А. В. Міфологічний код творів Гарта Крейна / А. В. Колісниченко // Актуальні питання гуманітарних наук. - Випуск 29. Дрогобич, 2020. - С. 92-96.

УДК 821.111 - 14 (73) (045) Крейн

\title{
МІФОЛОГІЧНИЙ КОД ТВОРІВ ГАРТА КРЕЙНА
}

КОЛІСНИЧЕНКО Анна Віталї̈вна, orcid.org/0000-0002-9596-3103 кандидат філологічних наук, дочент кафедри іноземних мов і прикладної лінгвістики Національного авіаційного університету М. Київ (Україна) Safronovaannar@gmail.com

Мета. Метою статті $\epsilon$ розкриття особливостей міфопоетики творчості Гарта Крейна; проаналізувати основні архетипні образи, універсальні та індивідуальні символічно-міфологічні комплекси у контексті світової та національної художньої традиції; конкретизувати історико-культурний контекст, взаємодію традиції і поетикальних експериментів модерністів як дієвий фактор формування світогляду митця; з'ясувати основні джерела запозичення класичних міфів та проаналізувати їхню художню трансформацію митцем; проаналізувати своєрідність міфологізації і семантизації артефактів і об’єктів сучасності в неоміфологічному художньому просторі Крейна; дослідити вербальний дискурс як фактор міфологізації; на основі здійсненого аналізу визначити особливості міфопоетики Крейна, що стали результатом цілеспрямованого формування поетом «нового міфу Америки». 
Методи. Методи розвідки визначені її проблематикою і завданнями, зумовили комплексне застосування елементів біографічного методу - для з'ясування факторів упливу особистого життя на становлення творчої особистості Гарта Крейна, що поєднується з порівняльно-історичним - для виявлення важливих віх національної художньої традиції та окреслення сучасного митцеві контексту появи його творів; архетипокритики, що дозволило з'ясувати первинні джерела поетичної образності митця; а також інструментарію міфокритики для вияву тих символів і міфологічних комплексів, що сформували авторський неоміф.

Результати. Здійснений комплексний аналіз міфопоетики Гарта Крейна в контексті літератури американського модернізму. Проаналізовані особливості складної взаємодії архаїчного міфу, національної художньої традиції феноменів модерної дійсності у створенні авторського неоміфу. Окреслені різнорідні міфологічні дискурси - індіанський, античний, християнський і т. д., їхня трансформація і синтез.

Висновки. Детальний аналіз міфологічних кодів творів Г. Крейна дав змогу 3'ясувати основні джерела запозичення класичних міфів та проаналізувати їхню художню трансформацію митцем. У розвідці зазначається, що, запозичуючи міфологеми 3 міфологій різних культур, Крейн зазвичай трансформував їх принагідно реалій сучасності, прагнучи крізь «вічний образ» ретранслювати своє бачення саме американського соціуму.

Ключові слова: міф, міфологізм, міфопоетика, синтез міфем, модерністська естетика, першостихії, гендер, фемінне, маскулінне .

\section{MYTHOLOGICAL CODE IN HART CRANE'S WORKS}

Kolisnychenko Anna Vitaliivna,

Candidate of Philological Sciences, Associate Professor of Department of Foreign Languages and Applied Linguistics 
Safronovaannar@gmail.com

orcid.org/0000-0002-9596-3103

Purpose. The purpose of the article is to research the features of mythopoetics of Hart Crane's works; to analyze the main archetypal images, universal and individual symbolic-mythological complexes in the context of world and national traditions; to specify the historical and cultural context, the interaction of tradition and the poetic experiments of modernists as an effective factor in poet's ideology formation; to find out the main sources of borrowing of classical myths and to analyze their poetical transformation by the poet; to analyze the peculiarity of mythologization and semantization of artifacts and objects of the present in Crane's neomythological poetical sphere; to explore verbal discourse as a factor of mythologization; to determine the features of Crane's mythopoetics that resulted from the purposeful formation of the "new myth of America" by the poet .

Methods. The methods of research are determined by its problems and tasks. It is supposed to apply elements of biographical method to find out the factors of influence of personal life on the development of poet's creativity. Using the comparative-historical method helps to identify important milestones of the national poetic tradition. Archetypocritics identifies the primary sources of the poet's imagery as well as a mythology toolkit to search symbols and mythological complexes that form author's neomyth.

Results. A comprehensive analysis of Hart Crane's myhopoetics in the context of American modernism is made. The peculiarities of the complex interaction of archaic myth, national poetic tradition and the phenomena of modern reality in the creation of the poet's neomyth are analyzed. Heterogeneous mythological discourses (Indian, ancient, Christian, etc.) and their transformation and synthesis are outlined.

Conclusions. A detailed analysis of the mythological code of Hart Crane's works makes it possible to find out the main sources of classical myths 
and analyze their poetic transformation by the author. In the research it is noted that by taking symbols from mythologies of different cultures Crane usually transformed them according to the realities of modernism, trying to rely his vision of American society through an "eternal image".

Key words: myth, mythologism, mythopoetics, synthesis of myths, modernism aesthetics, natural elements, gender, feminine, masculine.

\section{1. Вступ}

Гарт Крейн - визначний американський поет, який, попри значний внесок у розвиток літератури США та вагому роль у формуванні національної і художньої свідомості американського суспільства XX століття, до цього часу залишається незнаним українським читачем. Така ситуація склалася не тільки через відсутність перекладів лірики поета українською мовою (російською перекладено кілька віршів), а й через відсутність критичних розвідок з цієї теми. Хоча Гарт Крейн за своє коротке життя створив кількісно незначний поетичний доробок, який складається зі збірки поезій «Білі будівлі», низки розрізнених віршів, листів, есеїв та перлини його мистецького спадку - поеми «Міст», вже сучасні йому діячі культури розуміли його творчість як беззаперечно оригінальну й значиму, а сьогодні вона входить до канону американської літератури. Визначальною рисою творів Крейна $є$ настійливе намагання поета поєднати традицію, у їі найширшому сенсі - від ритуалу і моделі поведінки до класики національної літератури, і новітні віяння, знову ж таки у широкому смислі - від наукових здобутків до експериментальної поетики літератури модернізму. Саме через цю складну і різнорівневу природу творчості поета неможлива іiі однозначна естетично-стильова ідентифікація. Тому Адріано Мораес Мігліавацца пояснює несхвальний відгук критики про твори Крейна тим, що поет був занадто радикальним у прагненні віднайти «золоту середину» між новаторством і традицією (Migliavacca, 2010). 
Через епатажну, бунтарську поведінку, притаманну його неординарній особистості, Гарт Крейн постійно був у центрі суспільної уваги, що посилювало інтерес і до його творів. Критики 1920-х років, які не розрізняли поета й ліричного героя і часто сприймали його поезії як дзеркальне відтворення приватного життя, спрямоване на виклик i порушення суспільних табу, здебільшого говорили про нетрадиційну сексуальну орієнтацію Крейна та ії проекцію в художній площині творів. Взявши за основу гомо(бі)сексуальні патерни поведінки поета, Роберт Мартін започаткував так звану «гомосексуальну критику», послідовники якої донині абсолютизують чуттєвість, сексуальність і гендерні аспекти поезії Гарта Крейна, у такий спосіб перетворивши його на іконічну постать гей-поезії та ледь не речника сучасних ЛГБТ-спільнот (Martin, 1998). Але його сміливий поетичний coming out - лише одна 3 іпостасей митця, лише одна 3 граней його лірики: ймовірно, цікава, безперечно, важлива і все ж - не головна.

Метою статті $є$ дослідження творчості Гарта Крейна як творця новітнього міфу, осердя якого - «міф Америки», що ліг в основу модерністського трактування американської ідентичності. Аналіз міфопоетики творчості Крейна уможливлює цілісне осмислення його художнього універсуму, з'ясування характерних для національної (США) та світової літератури ідейно-естетичних кластерів і концептів, що, притаманні складній i неоднорідній художній системі модернізму, визначили певні тенденції постмодерністської культури США.

\section{2. Міфопоетичний універсум Г. Крейна}

Гарта Крейна, навіть на тлі експериментаторства і екстравагантності сучасного пост-постмодерністського мистецтва, вирізняє оригінальне світобачення, те сприйняття дійсності, завдяки якому він бачив сакральне у звичному й буденному. Об'єктом його поклоніння й естетизації стали не традиційні культові об'єкти, не храми чи витвори мистецтва, але новітні артефакти - результат розвитку й досягнень людської думки і техніки: 
Бруклінський міст, літак, метро й т. п. Прикметно, що митець вбачав можливі перспективи розвитку сучасного суспільства лише при обов'язковій духовній еволюції людини, котра має супроводжувати безупинне стрімке вдосконалення і поширення технологій. Присутність технічних засобів у житті людини, що стали ії необхідним і непомітним компонентом, спонукала Крейна включити бездушні, але при цьому виразно характерні механічні / технічні символи до його поетичної системи образів. Так, збірка «Білі будівлі» отримала свою назву на честь величних хмарочосів, які Крейн вважав символом доби модернізму, свідченням людського прогресу. Ось такого органічного поєднання технічного, інтелектуального і духовного начал, синтезу успадкованих традицій, що є одночасно виявом історичної пам'яті нації і втіленням генію окремої людини, з новітніми віяннями прагнув Гарт Крейн міфотворець і поет-модерніст, рапсод нового часу і нової нації.

Міфопоетика митця - це синтезоване багатопланове і різнорівневе явище, в якому гармонійно поєднались, на перший погляд, чужорідні, дистанційовані у часі і просторі елементи. В художньому універсумі Гарта Крейна вони, 3 одного боку, функціонують як компоненти унікального національного міфу США - строкатого і заразом гомогенного, тобто такого, яким від зародження є і яким залишається донині «американський міф», а 3 іншого, завдяки всеприсутності й вічності константних міфем у національних міфологемах, вони утверджують органічність і підставність присутності Поетового, тобто авторського Міфу у національній і світовій міфології. Авторське, індивідуальне, одиничне як необхідний складник у системі загального, колективного, суспільного - так Крейн розумів і у такий спосіб утілив знаковий для американської державності й людності девіз «Е pluribus unum». Варто згадати, що авторство цього вислову приписують i Геракліту, і Цицерону, і Вергілію, тобто і греки, і римляни, представники різних епох, народів і культур одностайні у розумінні генези нового: 
тільки за умови взаємодії різних компонентів виникає якісно нове явище. Так бачив своє завдання і Гарт Крейн як творець національного епосу, що мав зібрати воєдино, гомогенізувати, але при цьому зберегти неповторність кожного окремого компоненту-міфеми, які сформували його художній світ. Тому цей світ складається 3 величезного числа міфологем, які так чи інакше були дотичні до формування й становлення не тільки США, але взагалі країн американського континенту.

Перший з міфологічних комплексів, який модифікує Гарт Крейн при створенні сакрально-універсального поетичного міфу Америки, це індіанський. Алюзіями на міфи корінного населення континенту марковані ледь не всі твори Крейна. Вони включають у себе міфи про походження світу, етіологічні, антропогонічні та ін., причому Крейн прагне підкреслити унікальність потрактування міфологеми ацтеками, майя чи північно-індіанськими племенами. Окрема тематична, легендаризована складова цих міфів - поява білих завойовників, котрі прагнуть не тільки захопити, але фізично заволодіти тілом континенту, що формує виразний гендерний дискурс (діалог фемінного й маскулінного) авторської рецепції та ії художньої ретрансляції. Одним із провідних мотивів Крейнових віршів є символічна передача досвіду від індіанців до білих поселенців, наприклад, фіалка від скво для маленького Ларрі в поемі «Міст». Взагалі флористичний мотив - від Персефони, через римські поховальні обряди й свята до індіанців і далі до американців початку XX століття на Бруклінському мосту - один 3 наскрізних і потужних, семантично насичених у авторській міфології Крейна. Тісні кореляції з індіанськими міфами у художньому просторі поезій американського поета мають міфологічні комплекси давніх греків, римлян, кельтів, які, вплетені в сюжет рефлексій ліричного героя, формують інформативно наснажений текст, що потребує для його більшменш адекватного прочитання активної i креативної співучасті ерудованого читача. У такий спосіб реалізується мета-ідея всієї творчості 
Крейна - взаємопереплетення і взаємопроникнення різнонаціональних міфологем у одному художньому просторі як переконливе свідчення вітальності «американського міфу».

\section{3. Християнська парадигма творів митця}

Гарта Крейна вирізняло 3-поміж його здебільшого релігійно налаштованих співвітчизників індиферентне ставлення до християнства як до однієї з багатьох релігій, що нарівні 3, наприклад, буддизмом, містить невичерпний арсенал придатних для використання сюжетів. Християнство для Крейна - це теж міфологія, що, так само, як i індіанська, вплинула на формування унікальної американської ідентичності. Головна 3 християнських міфологем, до якої постійно повертається у своїх творах Гарт Крейн, - це міфологема втраченого раю та пов'язані з нею міфеми древа пізнання або першодерева, першожінки як праматері, спокуси знанням і гріхопадіння як його наслідку, що для нащадків американських пуритан мало особливий сенс, зваживши на історію заснування США. Кожна з цих християнських міфем отримує додаткову конотацію, оскільки Крейн, активно використовуючи прийом доповнюваності, парадоксально зіставляе, зводить в одному реченні сакральний для християн образ (наприклад, Ісус Христос, його плоть i кров, його жертва, його смерть і воскресіння; бджоли і мед у Біблії) 3 язичницьким (відповідно, Діоніс, вино як його кров, його жертвопринесення як Загрея, його смерть і воскресіння; бджоли і мед в античній міфології), що, діалогічно відлунюючи і віддзеркалюючись, розширюють і інтелектуальний, і художній простір нового міфу - міфу Крейна і Америки. Підтвердженням цієї тези слугує поема «Міст», де притаманна американцям віра в те, що Америка - це Земля Обітована, втілилась у відчайдушному прагненні ліричного героя віднайти «американський» Катай, Ельдорадо, Авалон, Фулу, Атлантиду. Або створений Крейном образ чистилища, зрозуміло, нагадує канонічний опис 3 «Божественної комедії» Данте, але заразом і пекло, як його уявляють 
собі християни, хоч у кінцевому підсумку сукупно витворений образ більше схожий на те царство мертвих, котрим є Аїд у давньогрецькій міфології. У поемі Крейна саме спуск до «Аїду», наразі це вже метро, стає межовим моментом у процесі ініціації ліричного героя перед осягненням жаданого Катаю - чи то втраченого раю, чи то Землі Обітованої, а може, й Атлантиди, куди обіцяє привести тунель.

Християнська й язичницька міфології в парадигмі крейнівської міфопоетики реалізуються у візуальних чоловічих і жіночих образах.

Всупереч прийнятим гендерним нормам і стереотипам, для Гарта Крейна взірцем універсальної соціальної істоти є андрогін. Тому, цілеспрямовано і послідовно прагнучи «створення абсолютної поезії з ідеальним героєм для абсолютного читача» (Г. Крейн), поет намагався поєднати в одному образі - чи то людини, чи то природи, для нього не було посутнім, риси як фемінні, так і маскулінні. Наприклад, у частині «Аве Марія» 3 поеми «Міст» пальма, плоди якої символізують жіноче начало, обрисом силуету нагадує фалос - чоловіче начало, що сукупно й визначає їі сакральну функціональність у всіх задіяних поетом міфологемах.

\section{4. Першостихії в поезії Г. Крейна}

На міфологічний код художнього простору творів митця виразно накладена парадигма першостихій, представлена елементами води, вогню, повітря / вітру та землі. Найближчою Крейну є першостихія води, яка, здебільшого, ретранслює переживання та стримані емоції ліричного героя. Тож поезія Крейна передає весь спектр станів, що характерні для цієї стихії - від заспокійливо наснажливої, ласкаво материнської до бурхливої, загрозливої, нестримної. Поряд з цим вода - ще й хранителька історії та пам'яті, вона своїми глибинами урівноважує сучасне й минуле. Першостихія вогню - так само амбівалентна, як і вода, виступає як у ролі нищівної, так і очисної сили, а в поемі «Міст» Рука Вогню - це творчі сили митця, які він намагається пробудити, щоб словом створити міст (поему як 
міст між поетом і читачем і т. д.), як людські руки створили Бруклінський міст.

Першостихія повітря / вітру, здебільшого представлена в ранній ліриці поета, ірраціональна як сама природа. 3 одного боку - це стихія руйнації, що, подібно до вогню, знищує будівлі, ламає літаки й т. ін., а 3 іншого - це стихія спокою, смутку, котра, подібно до води, теж утримує пам’ять про пережите.

Значне місце у творчості Гарта Крейна посідає першостихія землі, яка представлена постійно повторюваними назвами географічних локусів, згадками про легендарно-історичні події в тому чи іншому місці. Одним із художніх засобів візуалізації першостихії землі у Крейна слугують міфологізовані образи або реальних історичних особистостей (Покахонтас, Колумб), або тих митців США, творчість яких змінила життя і свідомість співгромадян. Це здебільшого письменники XIX століття, ті класики, які заклали підвалини національної літератури - Емілі Дікінсон, Герман Мелвілл, улюблений Крейном Волт Вітмен, з яким він мав так багато спільного.Для нього багато значили слова Вітмена: «Нам мало всієї кулі земної чи окремої епохи // У мене будуть тисячі цих куль і увесь час» (Уитмен, 1944).

У поемі «Міст» першостихія землі персоніфікована особою індіанської принцеси Покахонтас, котра $\epsilon$ самою Америкою. Тією Америкою-індіанкою, яку завоював-освоїв білий чоловік (Колумб), яка дала перше потомство (Прісцилла Олден), діти якої (Ларрі) опановують традиції предків і конструюють літаки (брати Райт), з глибин якої виростає величний Міст.

Міст для Крейна - це провідник між минулим, сучасним і майбутнім, тобто часовий вектор набуває циклічної форми, як і сама арка мосту. Усі видозміни часопростору слугують кінцевій меті - ствердженню вічноприсутності, застиглості в часі Мосту (і всієї Америки). Реальний Бруклінський міст, втілення творчого генію американського народу, 
постав конденсованим, епічним символом творчих амбіцій і сподівань Гарта Крейна, котрий, як і всі американці, вірив у «міф Америки», у те, що його країна стане тим вічним Катаєм, де «небесним світочем підноситься і щедро розсипається любов» (Crane, 1966).

\section{5. Висновки}

Запозичуючи міфологеми 3 міфологій різних культур, Крейн зазвичай трансформував їх принагідно реалій сучасності, прагнучи крізь «вічний образ» ретранслювати своє бачення саме американського соціуму. Серед розмаїття міфів, використаних Крейном, чільне місце посідають міфи індіанців, корінного населення Америки. Поет віддав перевагу саме цим міфам, вважаючи їх одним 3 проявів питомо національних засад, без яких неможливе повноцінне відтворення американської духовності та ідентичності. Поєднуючи міфо-фольклорні образи різних народів чи не у кожному своєму вірші, Крейн у такий спосіб насичував їхню смислову площину множинністю можливих потрактувань.

\section{Список використаних джерел:}

1. Уитмен Уолт. Избранные стихотворения и проза. Москва. 1944. $218 \mathrm{c}$.

2. Crane H. Complete Poems and Selected Letters and Prose of Hart Crane. New York: Garden City. 1966. 302 p.

3. Martin R. The homosexual tradition in American poetry. Iowa: University Of Iowa Press. 1998. 280 p.

4. Migliavacca A. Hart Crane. His Poetry in Presence and Meaning. Porto Alegre. 2010. 49 p.

\section{References:}

1. Uitmen Uolt. (1944). Izbrannyye stikhotvoreniya i proza. [Selected poems and prose]. Moskva, 218 [in Russian].

2. Crane H. (1966). Complete Poems and Selected Letters and Prose of 
Hart Crane. New York: Garden City. 302 p.

3. Martin R. (1998). The homosexual tradition in American poetry. Iowa: University Of Iowa Press. 280 p.

4. Migliavacca A. (2010). Hart Crane. His Poetry in Presence and Meaning. Porto Alegre. 49 p.

Стаття надійшла в редакцію 25. 03. 2020 р. 